\title{
Conferences/Seminars
}

\section{The Eighteenth Annual Conference of the Association of Muslim Social Scientists}

\author{
Brockport, New York \\ Rabi ' al Awwal 28-30, 1410/October 27-29, 1989
}

The Annual Conference of the Association of Muslim Social Scientists (AMSS) has acquired a certain niche for itself in the academic life of Muslims in North America. Each year the Conference is attended by Muslim and several non-Muslim scholars from across North America and overseas.

The 18th Annual Conference was held in conjunction with the 15th Annual Conference of the Association of Muslim Scientists and Engineers (AMSE). This provided an opportunity for exchange of ideas among specialists from various disciplines. It was coordinated by the AMSS Vice President Dr. Salahuddin Malik. In all, some forty papers on Islam and Muslims were presented followed by interesting discussions.

Dr. Tāhā J. Al- 'Alwānī, President of the International Institute of Islamic Thought (IIIT) was the keynote speaker at the Banquet. The Isma' il and Lamya' al Fārūqi Memorial Lecture was delivered by Dr. Ralph Braibanti of Duke University. One highlight of the Conference was the well-attended Interfaith Trialogue which was addressed by Dr. James Evans of Colgate Divinity School, Dr. Tamara Sonn of St. John Fisher College, Rabbi Judea Miller of Rochester, NY, and Dr. Jamal Badawi of Halifax University, Nova Scotia, Canada.

The Conference, which was spread over twelve sessions, included eighteen panels on a variety of subjects.

The First Session comprised two panels: Business and Economics in Islam where Dr. Ausaf Ali reflected on the "Systemized Theory of the Islamic Economy." Dr. M. E. Biraima's paper, which was presented in his absence, discussed "A Qur'anic Model For a Universal Economic Theory." Dr. Hisham Ahmad of the University of Chicago spoke about the "Qur'anic Perspective on the Creation and Distribution of Wealth and Economic Justice," while Mohamed R. Bouzakuk of the University of Oklahoma spoke on "Ibn Khaldun: The Economist."

The parallel panel on Language and Education featured Dr. M. A. Waheed Fakhri of Chicago State University who introduced the 1989 survey of fulltime Islamic Schools in North America. Dr. Ni'mat H. Barazangi of Cornell spoke on "North American Parents and Children: Theoretical Model for Islamization of Education," and Dr. Kamal Nimer of the Islamic Saudi Academy focused on adult education. 
The Second Session had a panel on Islamic personalities where Muhammad A. Al-Buraey of King Fahd University of Petroleum and Minerals at Dhahran presented a paper on "Prophet Muhammad as an Agent of Change." Other papers in this session included Abubaker Al-Shingieti's (The University of Massachusetts) paper on Malcolm X, Sheikh Safiullah's (University of Utah) paper on Umar bin Abd al-Aziz, and Saeed Ahmad's (Boston University) paper on Sheikh Ahmad Sirhindi.

This panel had a special highlight when Dr. Muhammad Mustafa alAzmi of the Center for Hadith Analysis gave a presentation on the computerization of Hadith on compact laser disc in multiple languages.

The parallel panel, dedicated to Islam, the Individual and Muslim SelfConsciousness, had Mohamed el-Behairy of the State University of New York at Buffalo speaking on "Islam and Nationalism," while M. Zohair Husain of the University of South Alabama discussed Ali Shariati as a revolutionary Muslim modernist. Assad Basool of the American Islamic College spoke on the contemporary relevance of Islam and Hakim Rashid of Howard University compared concepts of self-esteem in Islam and the West.

The Third Session, first panel, which dealt with "Islam, Art and Architecture" had Muhammad Yusuf Siddiq of Harvard discussing "An Islamic Approach Towards the Study of Archaeology, Art and Architecture." Riyad Mahayani of Iowa State University talked about "Makkah and its Future Parameters," followed by Hussain Ateshin of Eastern Mediterranean University, Turkish Republic of Northern Cyprus who spoke about a "Theory of Islamic Aesthetics" giving a "Critical Review of Western Scholars."

In the second panel of this session Louay Safi of Wayne State University discussed "Islamic Law and Society," Afak Haydar of Arkansas State University spoke about "Public Administration in Islam," and Jawwaad Rasheed, a Rochester, N.Y., lawyer talked about Women in the Islamic Tradition.

The Fourth Session, which was dedicated to Trends and Directions in Islamic Social Sciences, was addressed by Dr. Tāhā J. Al- 'Alwānī, President of IIIT and Dr. Mona Abul-Fadl, Director of the Western Thought Project of IIIT.

The Fifth Panel did not take place and the Sixth Panel was the Banquet mentioned earlier.

Session Seven had three parallel panels. Panel Seven was dedicated to the Muslim contribution to medicine and included papers by Dr. Amjad Hussain of Toledo, Ohio, on Ibn Sina, Dr. Shahid Athar of Indianapolis, IN., on "The Islamic Perspecitve in Medical Ethics," and Bahu Sultan Shaikh who focused on Islamic Ethirs for Students of Medicine.

Its parallel Panel in this Session concentrated on Islamization of Knowledge in which R. Mukhtar Curtis of Ann Arbor, MI, discussed an "Authentic Interpretation of Classical Islamic Texts," and Ghouse Shareef of Bellarmine 
College in Louisville, KY, presented a paper on "Integration of Natural and Social Sciences As a Qur'anic Requirement."

Islam and Africa was the topic of the Ninth Panel in this Session where Ambassador Tayyab Siddiqi, the Pakistani envoy in Zimbabwi, talked about "Recent Islamic Developments in Africa," while AbdulRahman Elnakib of King AbdulAziz University in Madinah, Saudi Arabia reflected on "Higher Education Trends in North Africa and Saudi Arabia."

In Session Eight, Panel Ten, which was focused on Islam and the West, Theodore Wright of SUNY at Albany spoke on "Islam in American Scholarship," while Sharifa Alkhateeb of IIIT brought attention to the "Textbook Image of Islam: An Empirical Study of Fairfax County.” Ralph Sisson and Frederick Gravetter of SUNY at Brockport presented the results of their research on "The Influence of Prejudice on Westerner's Perception of Muslim Names of Allah," and Marwan Obeidat of Yarmouk University, Jordan, rounded off these discussions with his presentation on the first American play written on Prophet Muhammad (ȘAAS).

Islamic Banking and Insurance was the focus of the Eleventh Panel where AbdilHameed Bashir of the University of Wisconsin at Madison presented empirical evidence on Islamic banking, Sami Sei Gandy of Atlantic Brokerage of Camden, NJ spoke on "Risk Management and Insurance within an Islamic Economy," followed Syed Iqbal Mahdi of Benedict College in Columbia, SC, who presented a review of performance and discussed issues and prospects of Islamic banking in Pakistan.

Islam and the West in the area of Media was the topic for Panel Twelve. Dilnawaz Siddiqui of Clarion University presented his "Mass Media Analysis: An Islamic Perspective," Omar Afzal of Cornell discussed "Islam and Western Media," Salahuddin Malik of SUNY at Brockport and AMSS Vice President talked about the relationship of the media, Islam and the local community, while Omer Bin Abdullah of IIIT exposed censorship in the United States giving an overview of the 'Rushdie Affair.'

The Thirteenth Panel zeroed in on Muslim America. Hakim Rashid of Howard University talked about "Education and Socialization of Afro-American Children" and Kathleen Moore of the Univesity of Massachusetts at Amherst presented "The Case for Muslim Constitutional Interpretative Activitiy in the United States."

The Fourteenth Panel which was on Islam and Social Sciences had Taysir Nashif of Essex County College discussing "Islamization of Knowledge and Revival of the Islamic Scholarly Legacy" and S. M. Sayeed of the University of Sind at Jamshoro, Pakistan presented his "Proposals for Compilation of An Islamic Atlas Showing the Significance of the Muslim Ummah.”

Islam and America was the topic for the Fifteenth Panel where Deborah Hassan of SUNY at Brockport discussed "Islamic Family Structure and the 
Muslim Family in the United States: Case Study of Rochester, NY"

The Sixteenth Panel, which was dedicated to the Status of the Indian Muslim minority had Abidullah Ghazi of Chicago's Iqra Foundation talking about Ram Mohan Rai's encounter with Islam. Mohammad Alam of Cornell reflected on the current trends in Hindu-Muslim riots in India. Omar Khalidi of MIT discussed "Arab Intervention on Behalf of the Muslim Minority: A Case Study of Indian Muslims." Laxmi Berwa, a Washington, DC based physician and leader of the 'low-born' Hindus talked about "Conversion of Untouchables to Islam: Religion as a Social Vehicle of Equality in India." Muhammad Islamuulah Khan of Clarion University' PA, discussed the prospects of India's Muslims in the 1990's.

The Seventeenth Panel was concerned with Social-Political Trends in Muslim Societies where Ghulam Nabi Fai of the Islamic Society of North America spoke about "Development Technology: Impact on Islamic Culture." Abid Abbas of Allama Iqbal Open University, Islamabad, Pakistan and Afak Haydar reflected on "The Future of Shariah Ordinance in Pakistan," while Najmi Junaid of Vanderbilt University spoke about "Female Labor Force Participation Rates in Pakistan" and Faramarz Rahbar of Iowa State University at Iowa presented "Guidelines for Reconstruction and Successful Management Planning in Afghanistan: A Social-Cultural Point of View."

The Eighteenth and last Panel, which was on Crescent Moon Sightings: Astronomy, Atmospheric Optics, Human Vision and Fiqh brought together Mohibullah Durrani of Columbia University and Syed Zafaruddin Saeed, Coordinator of the Moon Sighting Committee of New York.

Omer Bin Abdullah IIIT

Herndon, VA 